DOI https://doi.org/10.18551/rjoas.2018-11.29

\title{
THE INFLUENCE OF SPIRITUAL INTELLIGENCE ON JOB STRESS AND TURNOVER INTENTION
}

\author{
Manoppo Vinno Petrus \\ Doctoral Program, Faculty of Administrative Sciences, University of Brawijaya \& \\ State University of Manado, Indonesia
}

Astuti Endang Siti, Rahardjo Kusdi, Kusumawati Andriani*

Business Administration, University of Brawijaya, Indonesia

*E-mail: andriani kusuma@ub.ac.id

\begin{abstract}
This research aims to analyze and explain the influence of spiritual intelligence, job stress on turnover intention nurse. Explanatory research is done by applying survey method. This research was conducted in 4 (four) private hospitals in Manado City, North Sulawesi Province, Indonesia. The population used in this study is all nursing staff who are permanent employees with total 522 nurses. The number of sample is 227 respondents by using probability random sampling method and measurement of questionnaire with Likert scale. The Likert scale is a more systematic way of scoring the index. The Likert scale in this study used five (5) levels: strongly disagree (STS), disagree (TS), Neutral (N), agree (S) and strongly agree (SS). Data analysis method used is GSCA by using GeSCA program. The result of the research on hypothesis shows there is negative significant influence between spiritual intelligence to job stress, there is significant negative influence between spiritual intelligence on turnover intention and there is positive significant influence between job stress to turnover intention. The conclusion is spiritual intelligence has a significant and negative effect on job stress, spiritual intelligence has a significant and negative effect on turnover intention and positive significant influence between job stress to turnover intention.
\end{abstract}

\section{KEY WORDS}

Spiritual intelligence, job, stress, turnover intention.

An organization can be said succeed in managing human resources if the policies implemented can maintain employee stability, in the sense of being able to keep low rate of employee turnover. Employee turnover is a phenomenon that often occurs within an organization. It could be a resignation from the organization, dismissal or death of an organization member. Employee turnover can occur voluntarily or involuntary. Voluntary turnover or quit is an employee's decision to leave the organization or company voluntarily due to factors of how attractive the current job is, and the availability of other work alternatives. On the other side, involuntary turnover or employee dismissal is an employer's decision to terminate a work relationship and be uncontrollable to the employee who is experiencing it (Robbins, 2006). Turnover intention can occur due to job stress. Job stress is an unpleasant emotional state of an person that occurs when he feels uncertain about his ability to overcome constraints or obstacles that have high values (McGrath, 1976).

Job stress is the main reason or "contribution" of people to leave (turnover) their work (Moore, 2002). The impacts arise from job stress are increased absenteeism and followed by increased intention to quit (turnover intention) and actual turnover, both of which are very detrimental to the organization (Luthans, 2011).

Spiritual intelligence is the best or the highest and complete intelligence compared with other intelligences because this intelligence is based on spirituality or the psyche of human (Zohar and Marshall, 2000). Working environment that engaged spirituality can affect an organization's success by reducing staff turnover, stress, fatigue, and nonattendance 
(Moalemi, 2010; Eikzad, 2011). According to Chawla and Guda (2010) there is a strong negative relationship between spiritual intelligence and turnover intention.

\section{LITERATURE REVIEW}

Spiritual Intelligence. Zohar and Marshall (2000) respond Emmons challenge with their famous book, "Spiritual Quotient: Connecting with our Spiritual Intelligence". They describe the spiritual intelligence as the highest intelligence and defined it as the intelligence to achieve meaning or value, the core intelligence that put one's life in a broader and richer meaning, the intelligence to judge a person's actions or way of life more vigorously compared with others. In line with Emmons (2000), they also emphasize spiritual intelligence applies to humanist and atheist just as people who practice formal religious practices. They claimed that religion might improve spiritual intelligence, but spiritual intelligence is not dependent on religion. They also provide the criteria used to evaluate and measure someone's spiritual intelligence.

The results of Kathleen Noble's (2001) study described people with high spiritual intelligence have inner strength and resilience that makes them better able to adapt to overcome adversity. Kathleen Noble (2001) quoted resilience's definition from Norman Garmezy as " the process of, capacity for, or outcome of successful adaptation despite challenging or threatening circumstances".

Danah Zohar, in his book SQ: Spiritual Intelligence, The Ultimate Intelligence, assess that spiritual intelligence is a form of highest intelligence that combines two defined intelligences; intellectual intelligence and emotional intelligence. Spiritual intelligence is regarded as the highest intelligence because it is engaging one's ability to put meaning in everything and considered as a way to feel happiness. This intelligence is the intelligence that lifts the function of the soul as an internal self-device that has the ability and sensitivity in seeing the meaning that is behind a certain object or event. Technically, the spiritual intelligence strongly associated with the event of meaning and value was first conceived and discovered by Danah Zohar and lan Marshall (2000). They bring up several indicators of high spiritual intelligence: the ability to be flexible, capacity to face and transcend pain, reluctance to cause unnecessary harm, dedicated and responsible leaders.

Job stress. Stress is an uncomfortable emotional state that occurs when a person feels unconvinced about his ability to overcome an important perceived challenge (McGrath, 1976). According to Davis and Newstrom (2008) job stress is a state of tension that affects the emotions, processes of the mind and the physical condition of a person. According to Davis and Newstrom (2008) job stress is caused by excessive workload, limited time in doing the job, lack of adequate responsibilities, differences in value with the company.

Turnover Intention. Turnover is the termination of an employee from his or her place of employment on a voluntary basis. Turnover intention is the tendency or intention of the employee to stop working from his work voluntarily at his own will (Zeffane, 1994). Robbins (1996), explains that turnover may occur voluntarily (voluntary turnover) or forced (involuntary turnover). According to Grant et al. (2001) turnover intention is an attitude tendencies or the degree to which an employee is likely to leave the organization or voluntarily resign from his job. Further described by Mobley, Horner and Holling Sworth, 1978 in Grant et al. (2001) the desire to move can be an early symptom of turnover in the company. The turnover intention can also be interpreted as the transfer of labor from the organization. Turnover may include resignation, transfer out of an organizational unit, dismissal or death of an organization member. According to Harnoto (2002) turnover intention by various matters concerning employee behavior, among others:, start being lazy at work, rising courage to violate work order, courage to oppose or protest to superiors, and losing seriousness to complete all employee responsibilities.

Hypotheses and Research Models:

$\mathrm{H}_{1}$ : Spiritual Intelligence Significantly Effect Job Stress;

$\mathrm{H}_{2}$ : Spiritual Intelligence Significantly Effect Turnover Intention;

$\mathrm{H}_{3}$ : Job Stress Significantly Effect Turnover Intention. 


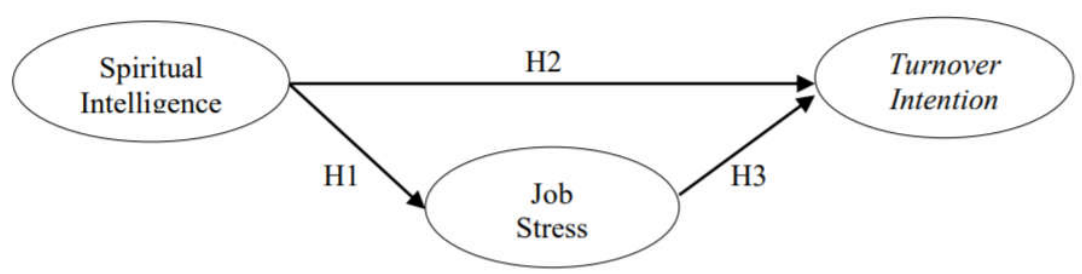

Figure 1 - Research Model

Research Variable and Indicator. Questionnaires in this study were compiled using Likert scale. Sofian Effendi in Singarimbun (1999) states that the Likert scale is a more systematic way of scoring the index. The Likert scale in this study used five (5) levels: strongly disagree (STS), disagree (TS), Neutral (N), agree (S) and strongly agree (SS).

\section{METHODS OF RESEARCH}

This type of research is explanatory research by applying survey method. The population used in this study is all nursing staff who are permanent employees, who work in four (4) private hospitals in Manado city with total 522 nurses. This study sizeing the samples using Slovin formula (1960) to obtain the total number of samples as many as 227 nurses. Based on the proposition number of nursing personnel in each hospital then the number of samples can be taken by random sampling by using proportional allocation.

The type of data in this study is quantitative data in the form of cross section data. While the data source comes from primary data and secondary data.

Validity Test is used to indicate the extent to which the data collected does not deviate from the condition of the variables in question. Validity is tested using Product Moment Pearson.

Convergent Validity 1st order is intended to find out whether the item is valid in measuring dimensions. Convergent validity 1 st order of each item in measuring dimension is indicated by the size of the loading factor. An item is said to be valid if loading factor is positive and bigger 0.6 . The results of complete testing can be seen in table 4.1. below this:

Based on the results of the analysis of 1 st order measurement model can be seen that all items of each variables of spiritual intelligence, job stress and turnover intention variables result in a loading factor greater than 0.6. Thus the item can be declared valid or able to measure variables.

Table 1 - Convergent Validity 1st Order (Item)

\begin{tabular}{|c|c|c|c|c|}
\hline Variable/ Dimension & Item & Loading Factor & Cut Off & Result \\
\hline \multirow{3}{*}{ Spiritual Intelligence (X) } & $\mathrm{X} 1$ & 0.820 & 0.6 & Valid \\
\cline { 2 - 5 } & $\mathrm{X} 2$ & 0.833 & 0.6 & Valid \\
\cline { 2 - 5 } & $\mathrm{X} 3$ & 0.794 & 0.6 & Valid \\
\hline \multirow{3}{*}{ Job Stress (Y1) } & $\mathrm{Y} 1.1$ & 0.774 & 0.6 & Valid \\
\cline { 2 - 5 } & $\mathrm{Y} 1.2$ & 0.902 & 0.6 & Valid \\
\cline { 2 - 5 } & $\mathrm{Y} 1.3$ & 0.916 & 0.6 & Valid \\
\cline { 2 - 5 } & $\mathrm{Y} 1.4$ & 0.884 & 0.6 & Valid \\
\hline \multirow{3}{*}{ Turnover Intention (Y2) } & $\mathrm{Y} 2.1$ & 0.903 & 0.6 & Valid \\
\cline { 2 - 5 } & $\mathrm{Y} 2.2$ & 0.914 & 0.6 & Valid \\
\cline { 2 - 5 } & $\mathrm{Y} 2.3$ & 0.923 & 0.6 & Valid \\
\cline { 2 - 5 } & $\mathrm{Y} 2.4$ & 0.928 & & \\
\hline
\end{tabular}

Source: Data processed by researchers, 2018.

Reliability Test is a tool to measure a phenomenon at different times and always give the same results. Reliability is tested using Alfa Cronbach formulation. Testing criteria if Cronbach's Alpha value is greater than 0.6 and discriminant reliability (AVE) value greater than or equal to 0.5 it can be stated that the construct has been reliable. The results of complete testing can be seen in Table 1. 
The reliability test above informs that ideal variables of spiritual intelligence, job stress and turnover intention variables produce AVE values greater than 0.5 . Thus, all items that measure variables are declared reliable or reliable. The reliability test above also informs that Cronbach's Alpha variables of spiritual intelligence, job stress and turnover intention variables worth greater than 0.6. Thus, all items that measure variables are declared reliable or reliable.

Descriptive statistical analysis Is used to determine the frequency distribution of respondents' answers from the questionnaire and describe the variables studied in depth.

Inferential statistical analysis Is used by GSCA for scores (not scalable) and can also be applied to very small samples and enables multicolinearity (Ghozali, 2008). The analytical tool used is GeSCA can be applied to structural models whose theoretical foundations are well established as confirmatory analyzes or on models whose theoretical basis is not yet well established, including reflective and formative indicators, the samples should not be large and the data should not be normally distributed.

\section{RESULTS OF STUDY}

Goodness of FIT Model. Based on a summary of Table 1. it can be seen that the value of GFI of 0.994 indicates that the value of GFI is greater than 0.9 . Thus the research model is declared feasible. FIT value of 0.583 , this can show that the variability of turnover intention variables can be explained by spiritual intelligence variables and job stress as a whole by $58.3 \%$, while the remaining $41.7 \%$ is explained by other variables not discussed in this study.

Table 2 - Goodness of FIT Model

\begin{tabular}{|c|c|}
\hline & Model Fit \\
\hline FIT & 0.583 \\
\hline AFIT & 0.579 \\
\hline GFI & 0.994 \\
\hline
\end{tabular}

Table 3 - Testing Hypothesis

\begin{tabular}{|c|c|c|c|}
\hline \multicolumn{3}{|c|}{ Path Coefficients } \\
\hline SI->JS & Estimate & SE & CR \\
\hline SI->TI & -0.155 & 0.076 & $2.05^{*}$ \\
\hline JS->TI & -0.154 & 0.064 & $2.43^{*}$ \\
\hline
\end{tabular}

${ }^{*} p<.05$

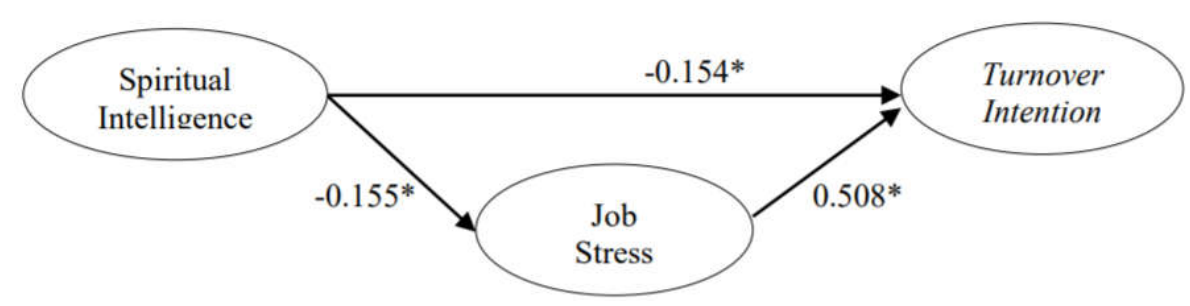

Figure 2 - Path Analysis Result

Hypothesis testing. Table 3 shows three test relationships between variables. It consists of spiritual intelligence towards job stress, spiritual intelligence towards turnover intention and job stress towards turnover intention. Out of the three, all indicates an significant relationship. The following will explain the relationship between each variable. Hypothesis test results as follows: (1) Hypothesis 1 is accepted. showing a significant negative influence of spiritual intelligence on job stress, (2) Hypothesis 2 is accepted, this shows significant negative effect of spiritual intelligence on turnover intention, (3) Hypothesis 3 is accepted, this shows a significant positive effect of job stress on turnover intention. 


\section{DISCUSSION OF RESULTS}

The Influence of Spiritual Intelligence on Job Stress. Spiritual intelligence has a significant positive effect on job stress because it obtained path coefficient of -0.155 with a critical ratio $(\mathrm{CR})$ of $2.05^{*}$ greater than 1.96 . This means the fifth hypothesis $(\mathrm{H} 1)$ is accepted.

King (2008) states that spiritual intelligence acts as a disorder in the relationship of stress and nonconformity. Job stress essentially refers to the conditions of the workers who threaten the individual. These threats may arise from job demands or because of the lack of individual needs. Job stress arises as a form of disharmony of individuals with the environment. The results of this study do not support previous studies conducted by Javadein et al. (2015) who said that spiritual intelligence has a significant negative effect on job stress. Then also does not support research conducted by Dela Pena (2010) who said that spiritual intelligence has a positive effect is not significant on job stress. But it supports research conducted by Gorji et al. (2014) that spiritual intelligence has a significant positive effect on job stress.

The Influence of Spiritual Intelligence on Turnover Intention. Spiritual intelligence significantly negatively influences the turnover intention because the path coefficient is obtained -0.154 with the critical ratio (CR) of $2.43^{*}$ which is greater than 1.96 . This means the fourth hypothesis $(\mathrm{H} 2)$ is accepted.

The application of spirituality in the workplace will stimulate employees to form a more positive perception of the organization so that employees will get change and achieve better adjustment through work with higher satisfaction, commitment to organization, organizational well-being and low willingness to turnover and absence Martin, et al. (2005).

The results of this study support previous studies conducted by Chawla and Guda (2010) who said that there is a strong negative relationship between spiritual intelligence and turnover intention and Rashvand and Bahrevar (2013) who also said that spiritual intelligence has a significant negative effect on turnover intention.

The Influence of Job Stress on Turnover Intention. Job stress has a significant positive effect on turnover intention because the obtained path coefficient of 0.508 with critical ratio (CR) of 6.19 is greater than 1.96. This means the fifth hypothesis $(\mathrm{H} 3)$ is accepted.

A nursing staff in a private hospital in Manado city should serve patients for 8 hours a day as their primary duty. Working for 8 hours can potentially lead to job stress. The behaviour of any patient who is often fussy when examined can make the nursing personnel experience stress. Likewise with the behavior of colleagues who are less helpful and only help when needed. In accordance with Moore's theory (2002) which stated that job stress is the main reason that contributed people to leave their jobs. This condition puts stress on physically, causing them to have a desire to leave the job (turnover intention).

The results of this study do not support previous research conducted by Paille (2011) who said that job stress affects positively insignificant to turnover intention. On the contrary, the results of this study support previous studies conducted by Azlina et al. (2012); Arshadi and Damiri (2012); Mosadeghrad (2013); Qureshi et al. (2013) who say that job stress affects significant positive toward turnover intention. This means that the higher the work stress perceived, the higher the intention turnover.

Research Limitation. This study only uses 3 variables that are suspected as cause of turnover intention. The three variables are spiritual intelligence, job stress and turnover intention. If this research use involves the broader variables such as organizational culture and others, it will probably give different results and can lead to different cause of turnover intention. Respondents from this study were nursing personnel in 4 (four) private hospitals in Manado City, so the conclusion was not generally applicable to all nursing staff in this case nursing staff working in government hospitals as civil state apparatus (ASN). 


\section{CONCLUSION}

The conclusion of this research is based on the research objectives: (1) Spiritual intelligence has a significant and negative effect on job stress, (2) Spiritual intelligence has a significant and negative effect on turnover intention, (3) Job stress has a significant and positive effect on turnover intention.

\section{REFERENCES}

1. Arshadi, N, Damiri, H. 2012. The Relationship of Job Stress with Turnover Intention and Job Performance: Moderating Role of OBSE. Procedia - Social and Behavioral Sciences 84 (2013) $706-710$.

2. Azlina, N, Basrib, Y.M, Kennedy. 2012. Relatioship Between Climate of Politics, Job Stress, Job Satisfaction and Turnover Intention Accounting Staff in Local Governments.

3. Bass, B.M. 1985, "From Transactional to Transformational Leadership : Learning to Share the Vision", Organizational Dynamics Vol. 18. No.3.

4. Davis, Keith and John W. Newstrom. 2008. Perilaku Dalam Organisasi. Jilid 1-2. Jakarta: PT. Erlangga.

5. Dela Pena III, S. 2010. Spiritual Intelligence and Work Stress among Basic Education Faculty of A Private Non-Sectarian School. Liceo Journal of Higher Education Research Social Science Section, Vol. 6 No. 2.

6. Ekong, E.A, Olusegun, A.A, Mukaila, O.A. 2013. Managerial Style and Staff Turnover in Nigerian Banks: A Comparative Analysis. American International Journal of Social Science Vol. 2 No. 6.

7. Emmons, Robert A. 2000. Spirituality and Intelligence: Problems and Prospects. The International Journal for The Psychology of Religion, 10(1), 57-64.

8. Ghozali, Imam. 2008. Model Persamaan Struktural Konsep and Aplikasi dengan Program Amos 16.0, Badan Penerbit UNDIP, Semarang.

9. Gorji, S.H, Mahmoudi, H.S, Lotfi, H. 2014. Relationship between Spiritual Intelligence and Job Stress in Male and Female Elementary Teachers, Behshahr, Iran. Spectrum: A Journal of Multidisciplinary Research Vol. 3 Issue 8.

10. Harnoto, 2002. Manajemen Sumber Daya Manusia. Prehallindo: Jakarta.

11. Javadein, S.R.S, Neshan, M.S, Moghaddam, M.M. 2015. Investigating the Effects of Spiritual and Emotional Intelligence on Nurses' Job Stress and Its Impact on Patient Satisfaction. Global Journal of Management Studies and Researches, 2(1), Pages: 1-8.

12. King, Ursula. 2008. The Search for Spirituality: Our Global Quest for A Spiritual Life: Blue Bridge.

13. Luthans, F. 2011. Perilaku Organisasi, Edisi Duabelas, Yogyakarta: Penerbit Andi.

14. Moalemi S. 2010. The Relationship Between Mental Health And Spiritual Intelligence In Sistan And Azad-Marzabadi E. et al. Journal of Military Medicine; 12(1):702-709.

15. Mosadeghrad, A. M. 2003. The Role of Participative Management (Suggestion System) in Hospital Effectiveness and Efficiency. Research in Medical Sciences, 8(3), 85-89.

16. McGrath, J. 1976. Stress and Behaviour in Organization. In M.D. Dunnette (Ed), Handbook of Industiral and Organizational Psychology (pp. 1351-1395) Chichago: Rand McNally.

17. Moore, K.A., 2002. Hospital Restructuring: Impact on Nurses Mediated by Social Support and A Perception of Challenge, J. Health Hum. Serv. Adm, 23: 490-517. PMDI: 11924310.

18. Noble, K. 2001. Riding the Windhorse: Spiritual Intelligence and the Growth of the Self. Cresskill, NJ: Hampton Press.

19. Paillé, P. 2011. Stressful Work, Citizenship Behaviour and Intention to Leave the Organization in a High Turnover Environment: Examining the Mediating Role of Job Satisfaction. Journal of Management Research, Vol. 3, No. 1: E1.

20. Qureshi, M, I, Mehwish, I, Abbas,S,G, Hassan,U, Khan,K and Zaman,K. 2013. Relationship Between Job Stress, Workload, Environment and Employees Turnover 
Intentions: What We Know, What Should We Know. World Applied Sciences Journal 23 (6): 764-770, 2013.

21. Rashvand, Omid, and Elham Bahrevar. 2013. "A Study of the Relationship among Spiritual Intelligence, Organizational Citizenship Behavior and Turnover Intentions." International Journal of Research in Organizational Behaviour and Human Resource Management 1.2: 25.

22. Robbins, Stephen P. 2006. Organization Theory: Structure, Design and Applications, Third Edition. Prentice Hall International Inc, Singapore.

23. Singarimbun, Masri and Sofian Effendi. 1989. Metode Penelitian Survei. Jakarta: LP3ES.

24. Zeffane, Rachid. 1994. Understanding Employee Turnover: The Need for A Contingency Approach, International Journal of Manpower, Vol. 15, No. 9, pp. 1-14.

25. Zohar, D. \& Marshall, I. 2000. SQ: Connecting With Our Spiritual Intelligence. New York: Bloomsbury Publishing. 